\title{
Klasyfikacja zapasów i gospodarowanie nimi w podmiotach rolniczych
}

\section{Wprowadzenie}

W ostatnich latach obserwuje się przesunięcie zapasów do producentów, natomiast $\mathrm{u}$ odbiorców i w jednostkach handlowych następuje ich ograniczanie. Jest to wynikiem możliwości łatwego i bezpośredniego zaopatrywania się w surowce i towary u producentów krajowych, dostępności importu, przy jednoczesnym występowaniu ograniczeń finansowych w przedsiębiorstwach. Ponadto, znaczny wpływ na te procesy ma stabilizowanie rynku, zwłaszcza w zakresie zaopatrzenia.

Środki obrotowe charakteryzują się dużą zmiennością w krótkim czasie, a zmiany dotyczą zarówno poziomu, struktury, jak i szybkości ich krążenia. Wszystko to znajduje odzwierciedlenie w sytuacji płatniczej przedsiębiorstwa i zmieniających się proporcjach między środkami własnymi i kredytem w finansowaniu aktywów obrotowych. Wynika stąd potrzeba stałej kontroli i analizy środków obrotowych oraz ciagłego, wielowariantowego planowania poziomu i struktury aktywów płynnych, zwłaszcza pod względem zapotrzebowania na kredyt. Przyśpieszenie rotacji aktywów płynnych, w tym także zapasów, pozwala na zmniejszenie zaangażowania śrođków finansowych, a dalszym efektem tych zmian może być rezygnacja $\mathrm{z}$ części lub całości kredytu bądź przeznaczenie powstałej nadwyżki na rozwój działalności.

Istotne jest, aby gospodarowanie zapasami było efektywne, tak aby nakłady na te środki nie stały się nadmierne. Przedsiębiorstwo powinno określić optymalny poziom inwestowania w zapasy, a robiąc to należy pogodzić dwa sprzeczne warunki. Po pierwsze, należy się upewnić, że poziom zapasów jest wystarczający na potrzeby produkcji i sprzedaży, po drugie, unikać utrzymywania nadwyżki zapasów, które są zbędne i mogą powodować wzrost ryzyka ich zestarzenia się. Optymalny poziom zapasów znajduje się pomiędzy dwoma wymienionymi ekstremami [Wasilewski 1999]. Na wielkość zapasów wyrobów gotowych $\mathrm{W}$ przedsiębiorstwie wpływają takie czynniki, jak [Napiórkowski 1973]: 
- pojemność magazynów wyrobów gotowych; może ona działać dwukierunkowo: zbyt duża powierzchnia może wywołać tendencje do gromadzenia wyrobów w nadmiernych ilościach, natomiast za mała powoduje trudności w prawidłowej organizacji czynności wysyłkowych i wpływa na powstawanie zbyt dużych zapasów,

- system rozliczania produkcji gotowej, np. w przedsiębiorstwach wytwarzających kompletne obiekty produkcyjne rozliczanie może następować według kompletnego obiektu lub według jego części,

- nadanie określonym zapasom w danym przedsiębiorstwie charakteru rezerwy,

- nieprawidłowości w rozliczaniu produkcji gotowej, polegające np. na zaliczaniu do wyrobów gotowych wyrobów niezakończonych.

Wpływ czynników finansowych na wielkość zapasów jest uzależniony od zainteresowania przedsiębiorstwa wynikami działalności. Powiązanie wielkości zapasów z kosztami wyraża się przede wszystkim w oddziaływaniu zapasów na koszty ich zakupu, utrzymania i sprzedaży oraz na finansowe możliwości inwestowania. W gospodarstwach rolniczych szczególnego znaczenia nabiera sezonowość produkcji i jej wpływ na poziom zapasów. Za zapasy sezonowe uważa się zapasy istniejące $z$ uwagi na wahania produkcji, zakupu i sprzedaży, jak również ze względu na sezonowe warunki transportu. Tak nieprecyzyjne kryterium umożliwia w praktyce zakwalifikowanie wielu takich samych zapasów zarówno do kategorii sezonowych, jak i bieżących bądź nadmiernych. Do zapasów zbędnych zalicza się nieprzydatne danemu przedsiębiorstwu do wykonywania jego obecnych lub przewidywanych w przyszłości zadań gospodarczych materiały i produkcję niezakończoną oraz wyroby gotowe, których przedsiębiorstwo nie może sprzedać w ramach obowiązujących warunków sprzedaży i cen. Kryterium to jest mało precyzyjne, szczególnie wówczas, gdy przedmiotem kwalifikacji ma być zapas objęty indywidualną normą bądź zapas części zamiennych do maszyn i urządzeń lub przedmiotów nietrwałych.

Urządzenia ewidencyjno-analityczne w księgowości przedsiębiorstw na ogół nie pozwalają w sposób jednoznaczny ustalić wielkości kosztów utrzymania zapasów, szczególnie w przedsiębiorstwach produkcyjnych. Można tam oszacować jedynie koszty magazynowania zapasów (płace personelu magazynowego, koszty amortyzacji budynków magazynowych, energii). Ponieważ jest to tylko część kosztów, ich udział w kosztach ogólnych jest niewielki. W związku $\mathrm{z}$ tym zjawisko nie jest analizowane. Nadal więc są naciski na utrzymywanie zapasów na wysokim poziomie bez analizy posiadanych stanów, rotacji, konieczności korekty norm zużycia, małe jest zainteresowanie zagadnieniem zagospodarowania zapasów zbędnych i nadmiernych, przedwczesnych zakupów bądź zamawiania w oderwaniu od potrzeb. 
Celem badań było określenie klasyfikacji rodzajowej zapasów według różnych kryteriów w gospodarstwach (przedsiębiorstwach) rolniczych, jak również ocena współpracy $z$ dostawcami środków do produkcji. Ponadto, przedstawiono klasyfikację zapasów wyrobów gotowych i zakupywanych środków do produkcji pod względem: stanów największych i najmniejszych, regularności zapotrzebowania i możliwości jego prognozy, jak również możliwości wyczerpania zapasów w różnych formach organizacyjno-własnościowych gospodarstw (przedsiębiorstw).

Badaniem objęto 95 gospodarstw indywidualnych, położonych w makroregionie środkowozachodnim według regionalizacji stosowanej przez Instytut Ekonomiki Rolnictwa i Gospodarki Żywnościowej (IERiGŻ). Wybrano wszystkie gospodarstwa prowadzące nieprzerwanie rachunkowość w okresie lat 1997-2000. Analizą zostały objęte gospodarstwa o powierzchni powyżej 15 ha użytków rolnych. Wprowadzono ograniczenie minimalnej powierzchni, gdyż w gospodarstwach mniejszych skala produkcji jest zbyt mała, jak również często wpływ pozarolniczych dochodów zniekształca rzeczywiste efekty produkcyjne i gospodarowania zapasami. Badania zostały również przeprowadzone w wielkoobszarowych przedsiębiorstwach rolniczych o powierzchni powyżej 500 ha użytków rolnych w ww. latach. Analizowano trzy grupy gospodarstw: dzierżawców ziemi od AWRSP ${ }^{1}$ (21 gospodarstw), gospodarstwa administrowane (37 gospodarstw) oraz jednoosobowe spółki AWRSP (10 spółek), położonych $\mathrm{w}$ makroregionie środkowozachodnim. Do badań przyjęto zatem łącznie 68 gospodarstw (przedsiębiorstw) rolniczych dobranych w sposób celowy lub obejmujących wszystkie gospodarstwa położone na terenie badanego makroregionu. Za podstawę wyboru przedsiębiorstw do badań posłużył wykaz dzierżawców nieruchomości przyjętych do Zasobu Skarbu Państwa przez OT AWRSP w Poznaniu i Bydgoszczy oraz wykaz gospodarstw pozostających w administrowaniu i jednostek (spółki komercyjne) ze 100-procentowym udziałem AWRSP.

Do określenia opinii zarządzających gospodarstwami dotyczących gospodarowania zapasami była wykorzystana metoda wywiadu standaryzowanego na podstawie kwestionariusza. Wywiady zostały przeprowadzone przede wszystkim z członkami zarządów badanych gospodarstw (przedsiębiorstw), prezesami spółek oraz właścicielami gospodarstw indywidualnych i dzierżawionych. Wywiady $\mathrm{z}$ przedstawicielami kadry kierowniczej miały szczególne znaczenie $\mathrm{z}$ uwagi na fakt, że to właśnie ta grupa pracowników odgrywała często najważniejszą rolę $\mathrm{w}$ procesie gospodarowania zapasami. Badania $\mathrm{z}$ wykorzystaniem kwestionariusza wywiadu przeprowadzono w okresie sierpień-grudzień $2000 \mathrm{r}$.

\footnotetext{
${ }^{1}$ Zgodnie $\mathrm{z}$ postanowieniami ustawy $\mathrm{z}$ dnia $11.04 .2003 \mathrm{r}$. o ksztaltowaniu ustroju rolnego (DzU Nr 64, poz. 592), która weszła w życie dnia 16.07.2003 r., Agencja Własności Rolnej Skarbu Państwa (AWRSP) zmieniła nazwę na: Agencja Nieruchomości Rolnych (ANR).
} 


\section{Wyniki badań}

Uwzględniając specyfikę gospodarstw rolniczych, w tabeli 1 przedstawiono propozycję klasyfikacji rodzajowej zapasów w gospodarstwach rolniczych według działów produkcji. Wydzielono dział produkcji roślinnej, zwierzęcej, przetwórstwa, usług, handlu oraz ogólnogospodarczy i ogólnoadministracyjny. W tabeli 2 natomiast przedstawiono klasyfikację zapasów według następujących kryteriów: stopnia koncentracji zapasów, technologii zaopatrzenia i produkcji, czasu, uwarunkowań rynkowych, wytwarzania i zakupu, rodzaju działalności, typu rolniczego gospodarstwa, przydatności zapasów, celu ich gromadzenia oraz działalności inwestycyjnej. Do realizacji celów badawczych w przypadku gospodarstw dzierżawców, administrowanych oraz spółek AWRSP przyjęto klasyfikację zapasów według ujęcia w bilansie majątkowym, zawartym w ustawie o rachunkọości [2002], z podziałem na materiały, półprodukty i produkty $\mathrm{w}$ toku, produkty gotowe $\mathrm{i}$ towary. Materiały stanowia nabyte od obcych kontrahentów i ewentualnie wyprodukowane przez własne komórki pomocnicze: surowce i inne materiały podstawowe, paliwa, materiały pomocnicze, opakowania, części zapasowe do maszyn i urządzeń, które są przeznaczone do zużycia na potrzeby wszystkich rodzajów własnej działalności produkcyjnej. W skład materiałów wchodzą również odpadki, produkty uboczne i odzyski, powstałe w toku produkcji lub innej działalności. W pozycji tej ujmuje się również wartość:

- materiałów odpisanych uprzednio w koszty bezpośrednio po zakupie, a niezużytych do końca roku obrotowego (na podstawie ich inwentaryzacji),

- materiałów w drodze, tj. tych, które jeszcze nie znajdują się fizycznie w posiadaniu jednostki gospodarczej, ale stanowiąjuż jej własność,

- inwentarza żywego, np. zakupionego do uboju.

Półprodukty i produkty w toku obejmują równowartość kosztów poniesionych na wytworzenie produktów (wyrobów i usług), które przeszły określone fazy produkcji, ale nie zostały zakończone - sq w toku realizacji. Produkcja $\mathrm{w}$ toku może występować w zakresie produkcji podstawowej i pomocniczej, obejmujących zarówno wytworzenie wyrobów, jak i świadczenie usług. W pozycji tej wykazuje się również wartość półproduktów, tj. tych produktów, które przeszły określone, zamknięte fazy produkcji, przeznaczone są do dalszego przerobu lub montażu i podlegają ewidencji ilościowo-wartościowej. Produkty gotowe obejmują wyroby gotowe, tj. takie produkty, które przeznaczone są do sprzedaży, nie podlegają dalszemu przerobowi w jednostce, w której zostały wytworzone, oraz odpowiadaja określonym normom lub warunkom umownym, a także roboty i usługi zakończone, lecz jeszcze niesprzedane do końca okresu sprawozdawczego. Do produktów gotowych nie zalicza się: 


\section{Tabela 1}

Klasyfikacja zapasów w gospodarstwach rolniczych według działów produkcji

\begin{tabular}{|c|c|c|}
\hline $\begin{array}{l}\text { Dział produk- } \\
\text { cji/charakter } \\
\text { działalności }\end{array}$ & Grupa zapasów & - Rodzaje zapasów \\
\hline \multirow{5}{*}{$\begin{array}{l}\text { Produkcja } \\
\text { roślinna }\end{array}$} & Produkty gotowe & $\begin{array}{l}\text { Zboża, ziemniaki, rzepak, rzepik, kukurydza, } \\
\text { strączkowe, buraki cukrowe, siano, słoma, ki- } \\
\text { szonki, włókniste, warzywa, tytoń, chmiel, jabłka, } \\
\text { kwiaty }\end{array}$ \\
\hline & $\begin{array}{l}\text { Materiały do produkcji } \\
\text { z zakupu }\end{array}$ & $\begin{array}{l}\text { Nawozy mineralne, środki chemicznej ochrony } \\
\text { roślin, sznurek do prasy słomy, kwalifikowany } \\
\text { materiał siewny, paliwo, wapno }\end{array}$ \\
\hline & $\begin{array}{l}\text { Produkcja niezakoń- } \\
\text { czona (półprodukty, } \\
\text { produkcja w toku) }\end{array}$ & $\begin{array}{l}\text { Według sumy kosztów poniesionych na dotych- } \\
\text { czasową produkcję w poszczególnych działalno- } \\
\text { ściach }\end{array}$ \\
\hline & Części zamienne & W zależności od rodzaju maszyny i urządzenia \\
\hline & $\begin{array}{l}\text { O charakterze inwe- } \\
\text { stycyjnym }\end{array}$ & $\begin{array}{l}\text { W zależności od rodzaju inwestycji, np. cement, } \\
\text { żwir, piasek, cegła, dachówka, pustaki itp. }\end{array}$ \\
\hline \multirow{5}{*}{$\begin{array}{l}\text { Produkcja } \\
\text { zwierzęca }\end{array}$} & $\begin{array}{l}\text { Stado obrotowe in- } \\
\text { wentarza żywego }\end{array}$ & $\begin{array}{l}\text { Prosięta, warchlaki, młode bydło opasowe, cie- } \\
\text { lęta, jagnięta, skopki, drób }\end{array}$ \\
\hline & Produkty gotowe & Mleko, welna, obornik, tucznik, jaja \\
\hline & $\begin{array}{l}\text { Materiał do produkcji } \\
\text { z zakupu }\end{array}$ & $\begin{array}{l}\text { Pasze treściwe, koncentraty, dodatki mineralne, } \\
\text { lekarstwa, paliwo, środki czystości, węgiel, olej } \\
\text { opałowy }\end{array}$ \\
\hline & Części zamienne & $\begin{array}{l}\text { W zależności od rodzaju maszyny, urządzenia, } \\
\text { budynku }\end{array}$ \\
\hline & $\begin{array}{l}\text { O charakterze inwe- } \\
\text { stycyjnym }\end{array}$ & $\begin{array}{l}\text { W zależności od rodzaju inwestycji, np. cement, } \\
\text { żwir, piasek, cegła, dachówka, pustaki itp. }\end{array}$ \\
\hline \multirow{3}{*}{$\begin{array}{l}\text { Przetwórstwo } \\
\text { rolne }\end{array}$} & Materiał do produkcji & $\begin{array}{l}\text { W zależności od rodzaju przetwórstwa, np. zbo- } \\
\text { że, warzywa, owoce }\end{array}$ \\
\hline & $\begin{array}{l}\text { Produkcja niezakoń- } \\
\text { czona (pólprodukty, } \\
\text { produkcja w toku) }\end{array}$ & $\begin{array}{l}\text { Według sumy kosztów poniesionych na dotych- } \\
\text { czasową produkcję, w zależności od rodzaju } \\
\text { przetwórstwa }\end{array}$ \\
\hline & $\begin{array}{l}\text { O charakterze inwe- } \\
\text { stycyjnym }\end{array}$ & $\begin{array}{l}\text { W zależności od rodzaju inwestycji, np. cement, } \\
\text { żwir, piasek, cegla, dachówka, pustaki itp. }\end{array}$ \\
\hline Handel & Towary & $\begin{array}{l}\text { W zależności od przedmiotu handlu, np. nawozy } \\
\text { mineralne, pasze treściwe, środki ochrony roślin, } \\
\text { węgiel }\end{array}$ \\
\hline Usługi & Usługowe & $\begin{array}{l}\text { W zależności od rodzaju świadczonych usług, np. } \\
\text { paliwo, środki chemicznej ochrony roślin, cement, } \\
\text { farby, wapno itp. }\end{array}$ \\
\hline $\begin{array}{l}\text { Ogólnogospo- } \\
\text { darczy }\end{array}$ & Ogólnogospodarcze & Paliwo na transport wewnętrzny, środki czystości \\
\hline $\begin{array}{l}\text { Ogólno- } \\
\text { administracyjny }\end{array}$ & Ogólnoadministracyjne & Materiały biurowe, środki czystości \\
\hline
\end{tabular}

Źródło: Opracowanie własne. 
- odpadów produkcyjnych - traktowanych jako zwrot materiałów zmniejszających koszt ich zużycia,

- materiałów wytworzonych na własne potrzeby - kwalifikowanych do materiałów,

- środków trwałych wytworzonych na własne potrzeby - ujmowanych w ramach majątku trwałego,

- towarów własnej produkcji, tj. wyrobów przekazanych własnym placówkom sprzedaży detalicznej oraz posiłków i wyrobów garmażeryjnych, sprzedawanych w stołówkach i bufetach - ich wartość ujmuje się łącznie $\mathrm{z}$ towarami nabytymi.

\section{Tabela 2}

Kryteria podziału zapasów w gospodarstwach rolniczych

\begin{tabular}{|l|l|l|}
\hline Kryterium podziału & Rodzaj zapasu & Działy produkcji \\
\hline $\begin{array}{l}\text { Stopień koncentra- } \\
\text { cji zapasów }\end{array}$ & $\begin{array}{l}\text { Minimalne, średnie, mak- } \\
\text { symalne }\end{array}$ & $\begin{array}{l}\text { Produkcja roślinna, produkcja zwie- } \\
\text { rzęa, przetwórstwo rolne, handel, } \\
\text { usługi }\end{array}$ \\
\hline $\begin{array}{l}\text { Technologia za- } \\
\text { opatrzenia i pro- } \\
\text { dukcji }\end{array}$ & $\begin{array}{l}\text { W drodze, cykliczne, } \\
\text { antycypacyjne }\end{array}$ & $\begin{array}{l}\text { Produkcja ró́linna, produkcja zwie- } \\
\text { rzęca, przetwórstwo rolne, handel, } \\
\text { usługi }\end{array}$ \\
\hline Czas & $\begin{array}{l}\text { Krótko-, średnio- i długo- } \\
\text { terminowe }\end{array}$ & $\begin{array}{l}\text { Produkcja roślinna, produkcja zwie- } \\
\text { rzęca, przetwórstwo rolne, handel, } \\
\text { usługi }\end{array}$ \\
\hline $\begin{array}{l}\text { Uwarunkowania } \\
\text { rynkowe }\end{array}$ & $\begin{array}{l}\text { Równomierne, nierów- } \\
\text { nomierne, bezpieczeń- } \\
\text { stwa }\end{array}$ & $\begin{array}{l}\text { Produkcja roślinna, produkcja zwie- } \\
\text { rzęca, przetwórstwo rolne, handel, } \\
\text { usługi }\end{array}$ \\
\hline $\begin{array}{l}\text { Wytwarzanie } \\
\text { i zakup }\end{array}$ & Własne i obce & $\begin{array}{l}\text { Produkcja roślinna, produkcja zwie- } \\
\text { rzęca, przetwórstwo rolne, handel, } \\
\text { usługi }\end{array}$ \\
\hline Rodzaj działalności & $\begin{array}{l}\text { Operacyjne, pozostałe } \\
\text { operacyjne, nadzwyczajne }\end{array}$ & $\begin{array}{l}\text { Produkcja roślinna, produkcja zwie- } \\
\text { rzęca, przetwórstwo rolne, handel, } \\
\text { usługi }\end{array}$ \\
\hline $\begin{array}{l}\text { Typ rolniczy } \\
\text { gospodarstw }\end{array}$ & $\begin{array}{l}\text { Pochodzenia roślinnego } \\
\text { i zwierzęcego }\end{array}$ & $\begin{array}{l}\text { Produkcja roślinna, produkcja zwie- } \\
\text { rzęca, przetwórstwo rolne }\end{array}$ \\
\hline Przydatność & $\begin{array}{l}\text { Niezbędny, dopuszczalne } \\
\text { wyczerpanie, zbędny }\end{array}$ & $\begin{array}{l}\text { Produkcja roślinna, produkcja zwie- } \\
\text { rzęca, przetwórstwo rolne, handel, } \\
\text { usługi }\end{array}$ \\
\hline Cel gromadzenia & $\begin{array}{l}\text { Do produkcji, do sprzeda- } \\
\text { zy }\end{array}$ & $\begin{array}{l}\text { Produkcja roślinna, produkcja zwie-- } \\
\text { rzęca, przetwórstwo rolne, handel, } \\
\text { usługi }\end{array}$ \\
\hline Inwestycyjne & $\begin{array}{l}\text { Jako lokata kapitału } \\
\text { w przypadku dużego } \\
\text { wzrostu cen, z przezna- } \\
\text { czeniem do produkcji }\end{array}$ & $\begin{array}{l}\text { Prọdukcja roślinna, produkcja zwie- } \\
\text { rzeca, przetwórstwo rolne, handel, } \\
\text { usługi }\end{array}$ \\
\hline
\end{tabular}

Źródło: Opracowanie własne. 
Towary stanowią rzeczowe składniki majątkowe nabyte od obcych kontrahentów, z przeznaczeniem do dalszej odsprzedaży, bez poddawania ich procesowi produkcji. Towarami są również artykuły spożywcze przeznaczone do przetworzenia na posiłki $w$ stołówkach i bufetach. W pozycji tej ujmuje się także wartość towarów w drodze, tj. tych, które jeszcze nie znajdują się fizycznie w posiadaniu jednostki, ale stanowia już jej własność. W gospodarstwach prowadzących rachunkowość dla IERiGZ wykorzystano natomiast podział zapasów ogółem na trzy ich kategorie: zapasy pochodzenia rolniczego (np. zboża, pasze treściwe, siano itp.), pochodzenia nierolniczego (np. nawozy mineralne, środki chemicznej ochrony roślin itp.) oraz obrotowy inwentarz żywy (na etapie tuczu, np. warchlaki).

Zdaniem większości zarządzających gospodarstwami, w umowie współpracy z dostawcami najistotniejsze jest zachowanie niezmiennej ceny w okresie jej obowiązywania, na co największą uwagę zwrócono w spółkach AWRSP ( $90 \%$ wskazań) a najmniejszą w gospodarstwach indywidualnych (69\% wskazań) (tab. 3). Równie istotne jest określenie częstotliwości dostaw oraz sprecyzowanie kar za niedotrzymanie standardów dostawy (obniżona jakość, opóźnienie dostawy). Na minimalną wielkość dostawy w danym okresie największą uwage zwrócili rolnicy indywidualni ( $28 \%$ wskazań), podczas gdy równoprawne traktowanie wszystkich odbiorców w zakresie ceny najbardziej istotne było w spółkach AWRSP (20\%). W gospodarstwach indywidualnych i administrowanych oraz dzierżawców dostawcy są w większości uprzedzani odpowiednio wcześnie o przewidywanym zapotrzebowaniu na środki do produkcji (61-87\% odpowiedzi). Zachowanie takie nie wystapiło w spółkach AWRSP, co argumentowano dostatkiem środków do produkcji na rynku. We wszystkich gospodarstwach $\mathrm{w}$ zdecydowanej większości (62-84\% odpowiedzi) dostawcy nie byli włączani do planowania skali produkcji i sprzedaży. W gospodarstwach indywidualnych argumentowano to zbyt małą skalą produkcji oraz brakiem zainteresowania dostawców taką formą współpracy (głównie z powodu nieznajomości zasad technologicznych $\mathrm{i}$ organizacji gospodarstw rolniczych). Podkreślano, że dużą skalą produkcji gospodarstw zainteresowani są głównie odbiorcy, którym zależy na jednorodnej jakościowo i dużej partii zakupu. W gospodarstwach pozostałych natomiast stwierdzono m.in., że dostawców jest wielu i co roku wybiera się najkorzystniejszego do danej grupy środków do produkcji, jak również nie ma potrzeby powiązań zwrotnych. W większości zarządzający gospodarstwami zamawiali środki do produkcji różnie w zależności o ich grupy, co dotyczyło zwłaszcza spółek AWRSP (70\% wskazań). $\mathrm{W}$ gospodarstwach indywidualnych i dzierżawców środki do produkcji były zamawiane, gdy ich zapasy się kończyły lub spadały poniżej poziomu uznawanego za bezpieczny (25-26\% wskazań). 30-31\% dzierżawców oraz zarządzających spółkami AWRSP zamawiało zapasy $z$ pewnym wyprzedzeniem $w$ określonych, stałych przedziałach czasowych. 
Tabela 3

Zasady współpracy gospodarstw z dostawcami środków do produkcji

\begin{tabular}{|c|c|c|c|c|}
\hline Wyszczególnienie & $\begin{array}{l}\text { Gospodar- } \\
\text { stwa } \\
\text { IERiGŻ }\end{array}$ & $\begin{array}{l}\text { Gospodar- } \\
\text { stwa } \\
\text { dzierżaw- } \\
\text { ców } \\
\end{array}$ & $\begin{array}{l}\text { Administro- } \\
\text { wane }\end{array}$ & $\begin{array}{l}\text { Spółki } \\
\text { AWRSP }\end{array}$ \\
\hline \multicolumn{5}{|c|}{ I. Zasadnicze elementy umowy z dostawcami środków produkcji (\% wskazań) } \\
\hline - czesstotliwość dostaw & 39 & 50 & 57 & 40 \\
\hline $\begin{array}{l}\text { - minimalna wielkośc dostawy } \\
\text { w danym okresie }\end{array}$ & 28 & 19 & 27 & 20 \\
\hline $\begin{array}{l}\text { - cena niezmienna w czasie } \\
\text { trwania umowy }\end{array}$ & 69 & 88 & 76 & 90 \\
\hline - długość trwania umowy & 16 & 19 & 27 & 30 \\
\hline $\begin{array}{l}\text { sprecyzowanie kar za niedo- } \\
\text { trzymanie standardów (np. ob- } \\
\text { niżona jakość, opóźnienie do- } \\
\text { stawy) }\end{array}$ & 36 & 25 & 32 & 40 \\
\hline $\begin{array}{l}\text { - niemożliwość sprzedaży kon- } \\
\text { kurentom }\end{array}$ & 1 & & 3 & \\
\hline - pozwolenie na zmiany cen & 12 & 19 & 14 & 20 \\
\hline $\begin{array}{l}\text { równoprawne traktowanie } \\
\text { wszystkich odbiorców, np. } \\
\text { w zakresie ceny }\end{array}$ & 18 & 6 & 5 & 20 \\
\hline \multicolumn{5}{|c|}{$\begin{array}{l}\text { II. Uprzedzanie dostawców odpowiednio wcześniej o przewidywanym zapotrzebowa- } \\
\text { niu gospodarstwa na środki produkcji (\%) }\end{array}$} \\
\hline - tak & 61 & 87 & 78 & - \\
\hline - nie & 39 & 13 & 22 & 100 \\
\hline \multicolumn{5}{|c|}{$\begin{array}{l}\text { lil. Włączanie dostawców do planowania skali produkcji i sprzedaży w gospodarstwie } \\
(\%)\end{array}$} \\
\hline - tak & 32 & 38 & 16 & 30 \\
\hline - nie & 68 & 62 & 84 & 70 \\
\hline \multicolumn{5}{|c|}{ IV. Moment zamawiania przez gospodarstwo środków produkcji (\% wskazań) } \\
\hline $\begin{array}{l}\text { - gdy zapasy się kończą lub } \\
\text { spadają poniżej poziomu } \\
\text { uznawanego za bezpieczny }\end{array}$ & 26 & 25 & 19 & \\
\hline $\begin{array}{l}\text { - z pewnym wyprzedzeniem, } \\
\text { w określonych stałych prze- } \\
\text { działach czasowych }\end{array}$ & 28 & 31 & 24 & 30 \\
\hline $\begin{array}{l}\text { - różnie w zależności od grupy } \\
\text { środków produkcji }\end{array}$ & 45 & 50 & 57 & 70 \\
\hline
\end{tabular}

Źródło: Badania wlasne. 
W gospodarstwach indywidualnych większość środków do produkcji była dostarczana w dniu zakupu, co dotyczyło zwłaszcza paliwa (69\% odpowiedzi), pasz treściwych dla bydła i trzody oraz koncentratów (tab. 4). W najmniejszym stopniu dotyczyło to nawozów mineralnych i pasz objętościowych obcych. W pozostałych grupach gospodarstw udział dostaw w tym samym dniu był niewielki, natomiast nie występowało takie zachowanie w gospodarstwach administrowanych i spółkach AWRSP przy dostawach nawozów mineralnych i pasz objętościowych obcych oraz pasz treściwych. W gospodarstwach wielkoobszarowych większość dostaw realizowano z opóźnieniem 1-5 dni. Dotyczyło to zwłaszcza pasz treściwych dla trzody i bydła, pasz objętościowych obcych i paliwa. Ten poziom opóźnienia występował także przy dostawach środków ochrony roślin, natomiast w relatywnie niewielkim stopniu dotyczył nawozów mineralnych. W gospodarstwach indywidualnych nawozy były dostarczane głównie $\mathrm{z}$ ww. opóźnieniem. Dostawy na poziomie opóźnienia 6-10 dni występowały głównie w gospodarstwach dzierżawców i administrowanych, zwłaszcza przy zakupach pasz objętościowych obcych, koncentratów oraz pasz objętościowych dla bydła. W $40 \%$ spółek w takim czasie były realizowane dostawy nawozów mineralnych, a w $29 \%$ gospodarstw indywidualnych dotyczyło to dostaw pasz objętościowych obcych. Dostawy realizowane $\mathrm{z}$ opóźnieniem 11-20 dni obejmowały nawozy mineralne i środki ochrony roślin głównie w gospodarstwach dzierżawców i spółkach AWRSP. Ta wielkość opóźnienia $\mathrm{w}$ gospodarstwach indywidualnych dotyczyła $\mathrm{w}$ największym stopniu pasz objętościowych obcych. W żadnej z grup gospodarstw opóźnienie w dostawach środków do produkcji z zakupu nie było większe niż 20 dni. Jednocześnie jednak dzierżawcy zwracali dużą uwagę na związek czasu realizacji zamówienia $\mathrm{z}$ posiadanymi zasobami środków pieniężnych, co dotyczyło zwłaszcza dostaw pasz objętościowych obcych, pasz treściwych dla trzody oraz nawozów mineralnych. W gospodarstwach administrowanych i spółkach AWRSP nie wystapiło uzależnienie czasu dostawy od posiadanych środków pieniężnych, a w gospodarstwach indywidualnych zależność taka była marginalna.

W analizowanych grupach gospodarstw na zbliżonym poziomie odpowiedzi wymieniano zapasy minimalne wyrobów wytworzonych we własnym gospodarstwie (84-90\%) (tab. 5). Zarządzający gospodarstwami jako zapasy najmniejsze kwalifikowali na ogół ziemniaki, buraki cukrowe oraz mleko. Zróżnicowanie pod względem rodzajów zapasów w tym zakresie było relatywnie niewielkie. W przypadku rodzajów zapasów o potrzebie ich stanów najwyższych zróżnicowanie było większe, a we wszystkich grupach gospodarstw wymieniano jedynie zapasy siana oraz kiszonki. Równie często wymieniano żyto (z wyjątkiem gospodarstw indywidualnych), pszenżyto ( $\mathrm{z}$ wyjątkiem gospodarstw dzierżawców) oraz słomę (z wyjątkiem spółek AWRSP). Przy ocenie 
rodzajów zapasów o stanach najniższych i najwyższych należy podkreślić powiązany charakter produkcji rolniczej, w której nawet mniejsze ilości zapasów mogą mieć duże znaczenie technologiczne. Również różnice w typach rolniczych gospodarstw przyczyniają się do zróżnicowania odpowiedzi dotyczących rodzajów najmniejszych i największych stanów zapasów.

\section{Tabela 4}

Przeciętny czas od złożenia zamówienia do zrealizowania dostawy ważniejszych środków produkcji (\%)

\begin{tabular}{|c|c|c|c|c|}
\hline Wyszczególnienie & $\begin{array}{c}\text { Gospodar- } \\
\text { stwa } \\
\text { IERiGZ }\end{array}$ & $\begin{array}{l}\text { Gospodar- } \\
\text { stwa dzier- } \\
\text { żawców }\end{array}$ & $\begin{array}{l}\text { Admini- } \\
\text { strowane }\end{array}$ & $\begin{array}{l}\text { Spółki } \\
\text { AWRSP }\end{array}$ \\
\hline 1 & 2 & 3 & 4 & 5 \\
\hline & \multicolumn{4}{|c|}{ w tym samym dniu } \\
\hline - nawozy mineralne & 19 & & & - \\
\hline - środki ochrony roślin & 43 & 7 & 14 & 10 \\
\hline - pasze treściwe dla bydła & 60 & 10 & 16 & 17 \\
\hline - pasze treściwe dla trzody & 54 & 17 & - & - \\
\hline koncentraty & 63 & 9 & 8 & 10 \\
\hline - pasze objetościowe obce & 29 & - & - & - \\
\hline - paliwo & 69 & 27 & 16 & 10 \\
\hline \multirow[t]{2}{*}{ - inne środki produkcji } & 50 & 11 & 14 & 11 \\
\hline & \multicolumn{4}{|c|}{$1-5 d n i$} \\
\hline - nawozy mineralne & 64 & 33 & 35 & 40 \\
\hline - środki ochrony roślin & 52 & 60 & 62 & 70 \\
\hline - pasze treściwe dla bydła & 35 & 50 & 78 & 83 \\
\hline - pasze treściwe dla trzody & 44 & 67 & 92 & 100 \\
\hline - koncentraty & 36 & 45 & 59 & 70 \\
\hline - pasze objetościowe obce & 29 & 25 & 95 & 100 \\
\hline - paliwo & 28 & 67 & 100 & 90 \\
\hline \multirow[t]{2}{*}{ - inne środki produkcji } & 47 & 22 & 46 & 56 \\
\hline & \multicolumn{4}{|c|}{$6-10$ dni } \\
\hline - nawozy mineralne & 13 & 20 & 30 & 40 \\
\hline - środki ochrony roślin & 2 & 7 & 14 & 10 \\
\hline - pasze treściwe dla bydła & 2 & 30 & 6 & - \\
\hline - pasze treściwe dla trzody & - & - & 8 & - \\
\hline - koncentraty & - & 36 & 19 & 10 \\
\hline - pasze objetościowe obce & 29 & 50 & 5 & - \\
\hline - paliwo & - & $\ldots$ & - & - \\
\hline - inne środki produkcji & 2 & 33 & 27 & 33 \\
\hline
\end{tabular}


cd. tabeli 4

\begin{tabular}{|c|c|c|c|c|}
\hline 1 & 2 & 3 & 4 & 5 \\
\hline & \multicolumn{4}{|c|}{$11-20 \mathrm{dni}$} \\
\hline - nawozy mineralne & 3 & 33 & - & 20 \\
\hline s srodki ochrony roślin & - & 20 & - & 10 \\
\hline - pasze tresciwe dla bydła & - & - & - & - \\
\hline - pasze tresciwe dla trzody & - & - & - & - \\
\hline - koncentraty & - & - & - & 10 \\
\hline - pasze objetościowe obce & 11 & - & - & - \\
\hline - paliwo & 1 & - & - & - \\
\hline \multirow[t]{2}{*}{ - inne środki produkcji } & - & - & - & - \\
\hline & \multicolumn{4}{|c|}{ zaleźy od zasobów środków pienjężnych } \\
\hline - nawozy mineralne & 1 & 14 & - & - \\
\hline - środki ochrony roślin & 3 & 6 & - & - \\
\hline - pasze tresciwe dla bydla & 3 & 10 & - & - \\
\hline - pasze tresciwe dla trzody & 2 & 16 & - & - \\
\hline - koncentraty & 1 & 10 & - & - \\
\hline - pasze objętościowe obce & 2 & 25 & - & - \\
\hline$\therefore$ paliwo & 2 & 6 & - & - \\
\hline - inne środki produkcji & 1 & 34 & - & - \\
\hline
\end{tabular}

Źródło: Badania własne.

Tabela 5

Zakładany poziom zapasów wyrobów wytworzonych w gospodarstwie

\begin{tabular}{|c|c|c|c|c|}
\hline Wyszczególnienie & $\begin{array}{l}\text { Gospodarstwa } \\
\text { IERiGŻ }\end{array}$ & $\begin{array}{c}\text { Gospodarstwa } \\
\text { dżierżawców }\end{array}$ & $\begin{array}{l}\text { Administro- } \\
\text { wane }\end{array}$ & $\begin{array}{c}\text { Spółki } \\
\text { AWRSP }\end{array}$ \\
\hline - Największy (\%) & 85 & 88 & 75 & 90 \\
\hline $\begin{array}{l}\text { najczęściej wymie- } \\
\text { niane produkty }\end{array}$ & $\begin{array}{l}\text { siano, słoma, } \\
\text { kiszonki, mie- } \\
\text { szanka zbo- } \\
\text { żowa, pszen- } \\
\text { żyto }\end{array}$ & $\begin{array}{l}\text { kiszonki, pa- } \\
\text { sze objęto- } \\
\text { ściowe, żyto, } \\
\text { słoma, siano }\end{array}$ & $\begin{array}{l}\text { kiszonki, } \\
\text { pszenżyto, } \\
\text { żyto, siano, } \\
\text { słoma, psze- } \\
\text { nica, mie- } \\
\text { szanka zbo- } \\
\text { żowa }\end{array}$ & $\begin{array}{l}\text { pszenica, } \\
\text { pasze objęto- } \\
\text { ściowe, ki- } \\
\text { szonki, pszen- } \\
\text { żyto, słoma, } \\
\text { siano, żyto, } \\
\text { jeczmień }\end{array}$ \\
\hline - Najmniejszy (\%) & 84 & 88 & 89 & 90 \\
\hline $\begin{array}{l}\text { najczęściej wymie- } \\
\text { niane produkty }\end{array}$ & $\begin{array}{l}\text { ziemniaki, } \\
\text { pszenica, } \\
\text { buraki cukro- } \\
\text { we, mleko, } \\
\text { warzywa, } \\
\text { jęczmień }\end{array}$ & $\begin{array}{l}\text { pszenica, } \\
\text { mleko, buraki } \\
\text { cukrowe, rze- } \\
\text { pak, żywiec, } \\
\text { ziemniaki, } \\
\text { komponenty } \\
\text { paszowe, } \\
\text { jęczmień }\end{array}$ & $\begin{array}{l}\text { mieko, rzepak, } \\
\text { buraki cukro- } \\
\text { we, wełna, } \\
\text { ziemniaki }\end{array}$ & $\begin{array}{l}\text { mleko, rzepak, } \\
\text { buraki cukro- } \\
\text { we, wełna, } \\
\text { ziemniaki }\end{array}$ \\
\hline
\end{tabular}

Źródło: Badania własne. 
W przypadku największych stanów zapasów środków do produkcji z zakupu najbardziej zbliżone odpowiedzi wystapiły $\mathrm{w}$ gospodarstwach indywidualnych i spółkach AWRSP (około 80\% odpowiedzi) (tab. 6). Najbardziej zdywersyfikowanych odpowiedzi, dotyczących wymienionych rodzajów zapasów, udzielono $\mathrm{w}$ gospodarstwach administrowanych. We wszystkich grupach gospodarstw potrzeba utrzymywania największych stanów zapasów dotyczyła głównie pasz treściwych dla bydła $\mathrm{i}$ trzody. Zbliżone zależności w zakresie jednoznaczności odpowiedzi wymienionych rodzajów zapasów wystapiły także przy ich stanach najmniejszych. We wszystkich grupach gospodarstw wymieniano bowiem głównie środki ochrony roślin, paliwo oraz nawozy mineralne.

\section{Tabela 6}

Zakładany poziom zapasów środków do produkcji z zakupu

\begin{tabular}{|c|c|c|c|c|}
\hline Wyszczególnienie & $\begin{array}{l}\text { Gospodar- } \\
\text { stwa IERiGŻ }\end{array}$ & $\begin{array}{c}\text { Gospodar- } \\
\text { stwa dzier- } \\
\text { żawców }\end{array}$ & $\begin{array}{l}\text { Administro- } \\
\text { wane }\end{array}$ & $\begin{array}{l}\text { Spóki } \\
\text { AWRSP }\end{array}$ \\
\hline - Największy (\%) & 81 & 75 & 50 & 80 \\
\hline $\begin{array}{l}\text { najczęściej wymieniane } \\
\text { produkty }\end{array}$ & $\begin{array}{l}\text { pasze dla } \\
\text { bydła i trzo- } \\
\text { dy, dodatki } \\
\text { mineralne, } \\
\text { koncentraty }\end{array}$ & $\begin{array}{l}\text { pasze dla } \\
\text { bydła i trzo- } \\
\text { dy, koncen- } \\
\text { traty, węgiel }\end{array}$ & $\begin{array}{l}\text { pasze dia } \\
\text { bydla i trzo- } \\
\text { dy, owies } \\
\text { z zakupu }\end{array}$ & $\begin{array}{l}\text { koncentraty, } \\
\text { pasze dla } \\
\text { bydła i trzody }\end{array}$ \\
\hline - Najmniejszy (\%) & 91 & 81 & 50 & 90 \\
\hline $\begin{array}{l}\text { najczęściej wymieniane } \\
\text { produkty }\end{array}$ & $\begin{array}{l}\text { środki ochro- } \\
\text { ny roślin, } \\
\text { paliwo, leki } \\
\text { dla zwierząt, } \\
\text { nawozy mi- } \\
\text { neraine }\end{array}$ & $\begin{array}{l}\text { środki } \\
\text { ochrony ro- } \\
\text { ślin, paliwo, } \\
\text { nawozy mi- } \\
\text { neralne, zbo- } \\
\text { ża z zakupu }\end{array}$ & $\begin{array}{l}\text { czéści za- } \\
\text { mienne, pali- } \\
\text { wo, nawozy } \\
\text { wieloskładni- } \\
\text { kowe, środki } \\
\text { ochrony ro- } \\
\text { ślin } \\
\end{array}$ & $\begin{array}{l}\text { środki ochro- } \\
\text { ny roślin, } \\
\text { czesści za- } \\
\text { mienne, pali- } \\
\text { wo, pasze, } \\
\text { nawozy fos- } \\
\text { forowe } \\
\end{array}$ \\
\hline
\end{tabular}

Żródło: Badania własne.

W tabeli 7 przedstawiono klasyfikację zapasów pod względem możliwości ich wyczerpania. W nawiasach podano przeciętny poziom zapasów bezpieczeństwa poszczególnych ich rodzajów. Wymieniane zapasy środków do produkcji niemogące się wyczerpać były relatywnie zróżnicowane. Największa różnica pod tym względem w stosunku do pozostałych gospodarstw wystapiła w spółkach AWRSP. W gospodarstwach indywidualnych, dzierżawców oraz administrowanych jako zapasy, które nie moga się wyczerpać wymieniano paliwo i pszenicę. Rodzaje zapasów mogących wyczerpać się chwilowo w poszczególnych grupach gospodarstw były także zróżnicowane. Największa zgodność pod tym względem wystapiła przy zapasach koncentratów (z wyjątkiem gospo- 
darstw administrowanych) oraz zapasów dodatków mineralnych (z wyjątkiem gospodarstw dzierżawców). Dużo większa zgodność odpowiedzi wystąpiła przy klasyfikacji zapasów mogących się wyczerpać w dłuższym okresie (powyżej dwóch miesięcy). Wymieniano głównie zapasy ziemniaków, nawozów mineralnych oraz środków ochrony roślin. Należy nadmienić jednak, że w przypadku nawozów i środków ochrony roślin jest to w dużym stopniu spowodowane sezonowym zapotrzebowaniem, podczas gdy moment ich zastosowania w realizacji produkcji (technologii) ma bardzo duże znaczenie.

\section{Tabela 7}

Klasyfikacja zapasów pod względem możliwości ich wyczerpania

\begin{tabular}{|c|c|c|c|c|}
\hline $\begin{array}{l}\text { Wyszczegól- } \\
\text { nienie }\end{array}$ & $\begin{array}{l}\text { Gospodarstwa } \\
\text { IERiGZ }\end{array}$ & $\begin{array}{l}\text { Gospodarstwa } \\
\text { dzierżawców }\end{array}$ & $\begin{array}{l}\text { Administrowa- } \\
\text { ne }\end{array}$ & Spółki AWRSP \\
\hline $\begin{array}{l}\text { Srodki do } \\
\text { produkcji nie- } \\
\text { mogące się } \\
\text { wyczerpać }\end{array}$ & $\begin{array}{l}\text { zboża paszowe } \\
(18,2 \mathrm{dt}) \\
\text { słoma }(33,8 \mathrm{dt}) \\
\text { paliwo }(101 \mathrm{l}) \\
\text { pszenica }(6,7 \\
\mathrm{dt})\end{array}$ & $\begin{array}{l}\text { zboża paszowe } \\
(215 \mathrm{dt}) \\
\text { paliwo }(1800 \mathrm{l}) \\
\text { pszenica }(111 \\
\mathrm{dt}) \\
\text { kiszonka }(6333 \\
\mathrm{dt})\end{array}$ & $\begin{array}{l}\text { owies }(210 \mathrm{dt}) \\
\text { siano }(215 \mathrm{dt}) \\
\text { stoma }(265 \mathrm{dt}) \\
\text { pszenica }(150 \\
\mathrm{dt})\end{array}$ & $\begin{array}{l}\text { paliwo }(2300 \mathrm{l}) \\
\text { mieszanka } \\
\text { zbożowa }(203,5 \\
\mathrm{dt}) \\
\text { owies }(90 \mathrm{dt}) \\
\text { kiszonka }(5150 \\
\mathrm{dt})\end{array}$ \\
\hline $\begin{array}{l}\text { Srodki do } \\
\text { produkcji } \\
\text { mogące się } \\
\text { chwilowo } \\
\text { wyczerpać } \\
\text { (np. 2-3 tygo- } \\
\text { dnie) }\end{array}$ & $\begin{array}{l}\text { koncentraty } \\
(2,3 \mathrm{dt}) \\
\text { dodatki mine- } \\
\text { ralne }(17 \mathrm{~kg}) \\
\text { siano }(18,5 \mathrm{dt}) \\
\text { polfamiksy }(7 \\
\mathrm{kg}) \\
\end{array}$ & $\begin{array}{l}\text { koncentraty }(3,5 \\
d t) \\
\text { otręby pszenne } \\
(21,5 \mathrm{dt}) \\
\text { siano (88 dt) }\end{array}$ & $\begin{array}{l}\text { dodatki mine- } \\
\text { ralne }(23 \mathrm{~kg}) \\
\text { nawozy mine- } \\
\text { ralne }(8 \mathrm{dt})\end{array}$ & $\begin{array}{l}\text { pszenica }(226,2 \\
\mathrm{dt}) \\
\text { koncentraty } \\
(120 \mathrm{dt}) \\
\text { dodatki mine- } \\
\text { ralne }(21 \mathrm{~kg})\end{array}$ \\
\hline $\begin{array}{l}\text { Srodki do } \\
\text { produkcji } \\
\text { mogące się } \\
\text { wyczerpać } \\
\text { w dłuższym } \\
\text { okresie (po- } \\
\text { wyżej } 2 \text { mie- } \\
\text { sięcy) }\end{array}$ & $\begin{array}{l}\text { ziemniaki } \\
\text { ( } 6,8 \mathrm{dt}) \\
\text { śruta rzepako- } \\
\text { wa }(1,7 \mathrm{dt}) \\
\text { środki ochrony } \\
\text { roślin (110 kg) } \\
\text { nawozy wielo- } \\
\text { składnikowe } \\
\text { (37 dt) } \\
\text { kiszonka } \\
\text { (4,6 dt) } \\
\text { oleje silnikowe } \\
\text { (8 I) } \\
\text { otręby (1 dt) }\end{array}$ & $\begin{array}{l}\text { nawozy mine- } \\
\text { raine }(50 \mathrm{dt}) \\
\text { środki ochrony } \\
\text { roślin }(250 \mathrm{~kg})\end{array}$ & $\begin{array}{l}\text { środki ochrony } \\
\text { roślin }(37 \mathrm{~kg}) \\
\text { otręby }(2 \mathrm{dt}) \\
\text { ziemniaki } \\
(74,8 \mathrm{dt})\end{array}$ & $\begin{array}{l}\text { jęczmień } \\
\text { (1000 dt) } \\
\text { nawozy mine- } \\
\text { ralne }(10 \mathrm{dt}) \\
\text { środki ochrony } \\
\text { roślin }(500 \mathrm{~kg})\end{array}$ \\
\hline
\end{tabular}

Źródło: Badania własne. 
W tabeli 8 przedstawiono klasyfikację zapasów pod względem regularności zapotrzebowania i możliwości prognozy. Do grup zapasów o regularnym zapotrzebowaniu z możliwością dokładnego zaplanowania zużycia zaliczono głównie koncentraty i paliwo (z wyjątkiem gospodarstw administrowanych). Należy podkreślić jednak relatywnie duże zróżnicowanie między gospodarstwami pod względem tego kryterium klasyfikacji zapasów. Dość duża była zgodność w zakresie zapasów środków do produkcji potrzebnych sezonowo, $\mathrm{z}$ możliwością zaplanowania ich zużycia $\mathrm{w}$ średnim stopniu. Wymieniano bowiem we wszystkich gospodarstwach głównie nawozy mineralne, środki ochrony roślin oraz materiał siewny. Do rodzajów zapasów środków do produkcji potrzebnych nieregularnie o niskiej możliwości zaplanowania ich zużycia zaliczono we wszystkich gospodarstwach części zamienne do maszyn oraz lekarstwa dla zwierzatit.

\section{Tabela 8}

Klasyfikacja zapasów pod względem regularności zapotrzebowania i możliwości prognozy

\begin{tabular}{|c|c|c|c|c|}
\hline Wyszczegóinienie & $\begin{array}{l}\text { Gospodar- } \\
\text { stwa IERiGŻ }\end{array}$ & $\begin{array}{l}\text { Gospodar- } \\
\text { stwa dzier- } \\
\text { żawców }\end{array}$ & $\begin{array}{c}\text { Administro- } \\
\text { wane }\end{array}$ & $\begin{array}{c}\text { Spółki } \\
\text { AWRSP }\end{array}$ \\
\hline $\begin{array}{l}\text { Środki do produkcji } \\
\text { regularnie potrzebne, } \\
\text { z możliwością dokład- } \\
\text { nego zaplanowania } \\
\text { zużycia }\end{array}$ & $\begin{array}{l}\text { koncentraty, } \\
\text { paliwo, sło- } \\
\text { ma, pasze } \\
\text { treściwe }\end{array}$ & $\begin{array}{l}\text { koncentraty, } \\
\text { premiksy, } \\
\text { zboże, pali- } \\
\text { wo, preparaty } \\
\text { mlekozastęp- } \\
\text { cze, śruta } \\
\text { rzepakowa }\end{array}$ & $\begin{array}{l}\text { owies, siano, } \\
\text { słoma } \\
\text { mieszanka } \\
\text { zbożowa }\end{array}$ & $\begin{array}{l}\text { koncentraty, } \\
\text { paliwo, pre- } \\
\text { miksy, zboża, } \\
\text { śruty zbożo- } \\
\text { we }\end{array}$ \\
\hline $\begin{array}{l}\text { Środki do produkcji } \\
\text { potrzebne sezonowo, } \\
\text { możliwe jest zaplano- } \\
\text { wanie ich zużycia } \\
\text { w średnim stopniu }\end{array}$ & $\begin{array}{l}\text { nawozy mine- } \\
\text { ralne, środki } \\
\text { ochrony ro- } \\
\text { ślin, materiał } \\
\text { siewny, sznu- } \\
\text { rek }\end{array}$ & $\begin{array}{l}\text { nawozy mine- } \\
\text { ralne, środki } \\
\text { ochrony ro- } \\
\text { ślin, paliwo, } \\
\text { materiał } \\
\text { siewny, kom- } \\
\text { ponenty pa- } \\
\text { szowe } \\
\end{array}$ & $\begin{array}{l}\text { nawozy mine- } \\
\text { ralne, środkj } \\
\text { ochrony ro- } \\
\text { ślin, sznurek, } \\
\text { materiał } \\
\text { siewny }\end{array}$ & $\begin{array}{l}\text { środki ochro- } \\
\text { ny roślin, } \\
\text { nawozy mine- } \\
\text { ralne, mate- } \\
\text { riał siewny, } \\
\text { wapno, pali- } \\
\text { wo }\end{array}$ \\
\hline $\begin{array}{l}\text { Srodki do produkcji } \\
\text { nieregularnie potrzeb- } \\
\text { ne, o niskiej możliwo- } \\
\text { ści zaplanowania ich } \\
\text { zużycia }\end{array}$ & $\begin{array}{l}\text { części do } \\
\text { maszyn, } \\
\text { lekarstwa dla } \\
\text { zwierząt }\end{array}$ & $\begin{array}{l}\text { części za- } \\
\text { mienne, } \\
\text { lekarstwa dla } \\
\text { zwierząt }\end{array}$ & $\begin{array}{l}\text { części za- } \\
\text { mienne, wę- } \\
\text { giel, wapno, } \\
\text { lekarstwa dla } \\
\text { zwierząt }\end{array}$ & $\begin{array}{l}\text { części za- } \\
\text { mienne, } \\
\text { materiały } \\
\text { budowlane, } \\
\text { lekarstwa dla } \\
\text { zwierząt }\end{array}$ \\
\hline
\end{tabular}

Žródło: Badania własne. 
Zarządzający gospodarstwami za najważniejszy obszar funkcjonowania gospodarstw uznali dopasowanie struktury produkcji do potrzeb gospodarstwa i wymagań rynku (tab. 9). Dotyczyło to zwłaszcza spółek AWRSP. Jako istotny obszar funkcjonowania gospodarstwa (na zbliżonym poziomie odpowiedzi) uznano także unowocześnianie i przestrzeganie technologii. Na umiejętność zarządzania zapasami produktów gotowych i środków do produkcji z zakupu największą uwagę zwrócili zarządzający gospodarstwami administrowanymi i spółkami AWRSP (odpowiednio 35\% i 30\% wskazań). Najmniejszą uwagę do tego czynnika przywiązywali rolnicy indywidualni, dla których istotna była głównie konkurencja na rynku (40\% wskazań).

\section{Tabela 9}

Najważniejsze obszary funkcjonowania gospodarstw rolniczych (\% wskazań)

\begin{tabular}{|l|c|c|c|c|}
\hline Wyszczególnienie & $\begin{array}{c}\text { Gospodar- } \\
\text { stwa IERiGż }\end{array}$ & $\begin{array}{c}\text { Gospodar- } \\
\text { stwa dzier- } \\
\text { zawców }\end{array}$ & $\begin{array}{c}\text { Admini- } \\
\text { strowane }\end{array}$ & $\begin{array}{c}\text { Spótki } \\
\text { AWRSP }\end{array}$ \\
\hline - konkurencja na rynku & 40 & 13 & 24 & 10 \\
\hline $\begin{array}{c}\text { - unowocześnianie i prze- } \\
\text { strzeganie technologii }\end{array}$ & 52 & 44 & 43 & 50 \\
\hline $\begin{array}{l}\text { - dopasowanie struktury pro- } \\
\text { dukcji do potrzeb gospodar- } \\
\text { stwa i wymagań rynku }\end{array}$ & 72 & 69 & 95 & 100 \\
\hline $\begin{array}{l}\text { - umiejętność zarzadzania } \\
\text { zapasami produktów wytwo- } \\
\text { rzonych w gospodarstwie } \\
\text { i środków do produkcji z za- } \\
\text { kupu }\end{array}$ & 13 & 25 & 35 & 30 \\
\hline
\end{tabular}

Źródło: Badania własne.

Większość zarządzających gospodarstwami nie zamierza w najbliższym okresie powiększać powierzchni gospodarstwa, co głównie dotyczyło gospodarstw administrowanych i spółek AWRSP (tab. 10). W największym stopniu powierzchnię gospodarstw zakładali powiększyć dzierżawcy (38\% odpowiedzi). Przed wypełnieniem kwestionariusza wywiadu aż $92 \%$ rolników indywidualnych nie wykorzystywało literatury dotyczącej gospodarowania zapasami. Najbardziej kreatywni w tym zakresie byli zarządzający gospodarstwami administrowanymi i spółkami AWRSP. 
Tabela 10

Stan wiedzy o zapasach i zamierzenia zarządzających gospodarstwami na przyszłość

\begin{tabular}{|l|c|c|c|c|}
\hline Wyszczególnienie & $\begin{array}{c}\text { Gospodar- } \\
\text { stwa IERiGż }\end{array}$ & $\begin{array}{l}\text { Gospodar- } \\
\text { stwa dzier- } \\
\text { zawców }\end{array}$ & $\begin{array}{l}\text { Administro- } \\
\text { wane }\end{array}$ & $\begin{array}{l}\text { Spółki } \\
\text { AWRSP }\end{array}$ \\
\hline $\begin{array}{l}\text { Czy gospodarstwo zamierza w najbliższym okresie powiększyć powierzchnię użytków } \\
\text { rolnych? (\%) }\end{array}$ & 28 & 38 & 0 & 10 \\
\hline - tak & 72 & 62 & 100 & 90 \\
\hline - nie & $\begin{array}{l}\text { nzy przed wypełnieniem kwestionariusza znana byla literatura zwiazana z metodami } \\
\text { gospodarowania zapasami? (\%) }\end{array}$ & 25 & 49 & 50 \\
\hline - tak & 8 & 75 & 51 & 50 \\
\hline - nie & 92 & & & \\
\hline
\end{tabular}

Źródło: Badania własne.

\section{Wnioski}

W opracowaniu przedstawiono analizę klasyfikacji rodzajowej zapasów według różnych kryteriów w gospodarstwach rolniczych, określono zapasy o stanach największych i najmniejszych pod względem regularności zapotrzebowania i dokładności prognozy, jak również możliwości wyczerpania zapasów. Na podstawie przeprowadzonych badań sformułowano następujące wnioski końcowe.

1. Coraz większą rolę, zwłaszcza w większych gospodarstwach rolniczych, odgrywa kwestia współpracy z dostawcami środków do produkcji na zasadzie umowy. Do zasadniczych jej elementów zaliczono niezmienną cenę, częstotliwość dostaw, jak również sprecyzowanie kar za niedotrzymanie standardów współpracy. Różnice pod tym względem między analizowanymi grupami gospodarstw rolniczych były niewielkie. Również zbliżony był moment zamawiania przez zarządzających gospodarstwami środków do produkcji z zakupu, tj. najczęściej w sposób zróżnicowany, w zależności od ich grupy. W większości gospodarstw uprzedzano dostawców o przewidywanym zapotrzebowaniu na te środki (z wyjątkiem spółek AWRSP). Przyczyniało się to na ogół do dużej terminowości dostaw środków do produkcji, zasadniczo z terminem realizacji do 5 dni. Rolnicy indywidualni kupowali środki do produkcji sami, zatem w zdecydowanej większości środki te były dostępne $\mathrm{w}$ dniu zakupu. Jednocześnie największe znaczenie zasobności gospodarstw w środki pieniężne i ich relacji do czasu dostawy środków do produkcji nadawali dzierżawcy. 
2. Rodzaje zapasów o koniecznych stanach największych i najmniejszych w grupach gospodarstw były zróżnicowane. Było to uzależnione od skali działalności, typu rolniczego gospodarstwa, jak również przyjętej strategii zaopatrzenia $\mathrm{W}$ środki do produkcji (samozaopatrzenie, zakupy $\mathrm{z}$ zewnątrz). Podobne zależności wystapiły przy klasyfikacji zapasów pod względem możliwości ich wyczerpania, regularności zapotrzebowania i możliwości jego prognozy. Oznacza to, że w dużej mierze poszczególne gospodarstwa rolne $o$ analizowanych typach organizacyjno-własnościowych należy traktować w sposób indywidualny. Zapotrzebowanie bowiem na określone rodzaje zapasów w ujęciu ilościowym i rodzajowym jest uzależnione od typu rolniczego gospodarstwa (przedsiębiorstwa) oraz przyjętej technologii produkcji. Zatem trudno w tej sytuacji określić standardowe (normatywne) wielkości poszczególnych rodzajów zapasów, które byłyby uniwersalnym zaleceniem dla ogółu gospodarstw rolniczych w badanym regionie. W gospodarstwach indywidualnych racjonalizację gospodarki zapasami pogarsza fakt przywiazywania do niej małej wagi oraz bardzo niewielka wiedza $\mathrm{z}$ tego zakresu, podczas gdy $\mathrm{w}$ gospodarstwach dużych (zwłaszcza spółkach AWRSP) zainteresowanie tym składnikiem majątku było duże.

\section{Literatura}

BASKIN A.I., 1997: Sterowanie zapasami w warunkach systemowych przekształceń gospodarki. Gospodarka Materiałowa i Logistyka nr 11, Warszawa.

BYLKA S., REMPAEA R., 2003: Wybrane zagadnienia matematycznej teorii zapasów. Akademicka Oficyna Wydawnicza EXIT, Warszawa.

NAPIÓRKOWSKI R., 1973: Instrumenty finansowe w gospodarce zapasami. PWE, Warszawa.

Ustawa o rachunkowości z dnia 29 września 1994 r. Tekst jednolity, DzU z 17 czerwca 2002 r., Nr 76, poz. 694.

WASILEWSKI M., 1999: Wybrane aspekty zarządzania zapasami w podmiotach rolniczych. W: Perspektywy rozwoju rachunkowości, audytingu i analizy finansowej. Wydawnictwo UG, Sopot.

WASILEWSKI M., 2003a: Ksztaltowanie poziomu i kosztów zapasów w gospodarstwach rolniczych. Roczniki Nauk Rolniczych, Seria G - Ekonomika Rolnictwa, tom 90, zeszyt 1.

WASILEWSKI M., 2003b: Klasyfikacja zapasów oraz tendencje ich zmian w gospodarstwach indywidualnych. Zeszyty Naukowe SGGW nr 48, Ekonomika i Organizacja Gospodarki Żywnościowej, Warszawa.

WASILEWSKI M., 2004: Uwarunkowania poziomu zapasów w indywidualnych gospodarstwach rolniczych. Postępy Nauk Rolniczych nr 2. 


\title{
The Classification and Management of Reserves in Farming Entities
}

\begin{abstract}
In the paper the classification of reserves according to many criterions is presented. The attempt of defying uniform groups of reserves with highest and lowest level as regards the regularity of demand and the possibility of running low in different organizational and property forms of agricultural farms was made. Within all groups of farms the rising role of cooperation with deliverers of factors to the production on the basis of trade contracts was observed. Resources to the production were ordered in different ways depending on the groups of resources. The time of delivery realization was shortest in private farms (mainly for the sake of direct purchase). Reserves characterized by highest and lowest states as well as regard the possibility of running low, the regularity of demand and possibility of forecasting were diverse between the groups of farms. The management of reserves in different organizational and property forms of agricultural farms should be treated individually. The normative determination of levels of reserves' types is difficult. In private farms the situation is worsened by the little farmers' knowledge about possibilities of reserves' managing rationalization.
\end{abstract}

